\title{
Remote sensing for cover change assessment in southeast Arizona
}

\author{
OSMAN C. WALLACE, JIAGUO QI, PHILIP HEILMA, AND ROBIN C. MARSETT
}

Authors are Research Scientist, Department of Geography/CGCEO, Michigan State University, East Lansing, Mich. 48824; Assistant Professor, Department of Geography/CGCEO, Michigan State University, East Lansing, Mich. 48824; Research Scientist, USDA-ARS Southwest Watershed Research Center, Tucson, Ariz. 85719; Research Scientist, USDA-ARS Southwest Watershed Research Center, Tucson, Ariz. 85719.

\section{Abstract}

Understanding landscape conversion is vital for assessing the impacts of ecological and anthropogenic disturbances at regional and global scales. Since rangelands cover nearly half of the global land surface, and because a large part of rangelands is located in semi-arid ecosystems, they serve as critical land cover types for determining regional biodiversity, global biogeochemical cycles, and energy and gas fluxes. For such vast ecosystems, satellite imagery is often used to inventory biophysical materials and manmade features on Earth's surface. The large area coverage and frequent acquisition cycle of remotely sensed satellite images make earth observation data useful for monitoring land conversion rates at different spatial scales. Remote sensing could also be used for temporal assessment of semi-arid ecosystems by providing complimentary sets of rangeland health indicators. In this paper, temporal satellite data from multiple sensors were examined to quantify land use and land cover change, and to relate spatial configuration and composition to landscape structure and pattern. The findings were correlated with the role of fire to better understand ecological functionality and human and/or natural activities that are generating environmental stressors in a rapidly developing, semi-urban census division located in southeastern Arizona. Results indicate that conversion of a fire-suppressed native grassland area has 2 spatial components; in the rural areas, grass is being eliminated by increasingly homogeneous shrub and mesquite-dominated areas, whereas in the urban and suburban areas, grass as well shrubs and mesquite are being eliminated by a fragmented and expanding built landscape.

Key Words: land conversion, landscape indices, fire suppression, rangeland maintenance, semi-arid, grasslands

Land cover change may be the most significant agent of global change; it has an important influence on hydrology, climate, and global biogeochemical cycles (Skole et al. 1997). Characterizing the forcing factors that drive changes in landscapes, and the resultant impacts on biogeochemical and hydrological cycles and energy and gas fluxes, is essential to understand the total Earth system and the effects of natural and human-induced changes on the global environment. Further, assessment of environmental responses to drivers of changes in land cover and land use, particularly in parts of the world that are currently undergoing the most stress, such as semi-arid rangelands, is an important function

Manuscript accepted 7 Dec. 02

\section{Resumen}

La conversión del paisaje que entiende es vital para evaluar los impactos de disturbios ecológicos y humanos en las escalas regionales y globales. Desde las praderas cubra casi la mitad de la superficie global de la pista, $y$ porque una parte grande de praderas está situada en los ecosistemas semiáridos, sirven como tipos críticos de la cubierta de pista para determinar biodiversitad regional, ciclos biogeoquímicos globales, y flux de la energía y del gas. Para tales ecosistemas extensos, las imágenes basadas en los satélites se utilizan a menudo para inventariar los materiales biofísicos y las características artificiales en la superficie de la tierra. La cobertura grande del área y el ciclo frecuente de la adquisición de imágenes basadas en los satélites remotamente detectadas hacen datos de la observación de la tierra útiles para vigilar índices de conversión de la pista en diversas escalas espaciales. La detección alejada se podía también utilizar para el gravamen temporal de los ecosistemas semiáridos proporcionando a conjuntos elogiosos de indicadores de la salud de las praderas. En estos datos basados en los satélites de papel, temporales de los sensores múltiples fueron examinados para cuantificar el cambio de la utilización del suelo y de la cubierta de pista, y para relacionar la configuración y la composición espaciales con la estructura y el modelo del paisaje. Los resultados fueron correlacionados con el papel del fuego para entender mejor funciones ecológicas y las actividades humanas y/o naturales que están generando las tensiones ambientales en rápidamente convertirse, división semi-urbana del censo localizaron en el Arizona del sudeste. Los resultados indican que la conversión de un área nativa fuego-suprimida del prado tiene dos componentes espaciales; en las áreas rurales, la hierba está siendo eliminada por el arbusto cada vez más homogéneo y las áreas mesquite-dominadas, mientras que en las áreas urbanas y suburbanas, se chiban también arbustos y el mesquite está siendo eliminado por un paisaje construido hecho fragmentos y que se amplía.

(Nemani et al. 1996). The benefits of such assessments include understanding the consequences of land cover and land use changes as they impact ecological processes, and evaluating which human activities contribute to changes occurring on the landscape.

Remotely sensed data are inherently suited to provide information on land cover characteristics related to ecological and dynamic aspects of developed regions at various spatial and temporal scales (Ridd 1995). However, few studies have looked at how remote sensing may be utilized to develop complimentary indicators for determining rangeland conditions. Recently, a con- 
sensus has been developing that environmental analysis requires a set of complementary indicators for a complete study of the causes and threats to ecological systems and for their protection and restoration (U.S. EPA 1997, 1999). Landscape indices quantify aspects of spatial pattern that can be correlated with ecological processes (O'Neill et al. 1988). In this context, numerous mathematical indices have been developed that allow the objective description of different aspects of landscape structure, function, and change. While traditionally satellite data were used to address questions concerning vegetation types and amounts, this paper asked a different question: How can satellite data be used to assess land conversion and cover change, study spatial configuration and composition of landscape elements, and, hence, assist in understanding the ecological integrity of a semi-arid grassland ecosystem?

The paper's main objective is to evaluate rangeland conditions through remotely sensed imagery in a census division that is undergoing rapid urban and suburban development. The utility of remote sensing as an ecological assessment tool will be determined by examining not only land use land cover change, but also the spatial arrangement and complexity of cover types in a semi-arid rangeland ecosystem. Finally, an assessment of changes correlates satellite findings with effects of fire suppression. The assessment is conducted for aiding in the development of sustainable land use practices, successful regional planning, and effective policy implementation.

\section{Materials and Methods}

\section{Study Area}

The formerly rural Sierra Vista $(31.6 \mathrm{~N}$, $110.3 \mathrm{~W}$ ) census division is a thriving community of 55,000 that serves as the regional urban center for southeastern Arizona (Figs. 1 and 2). Located approximately 120 kilometers southeast of Tucson, Ariz., the city is surrounded by the Huachuca, Dragoon, and Mule Mountains, and is bordered on the east by the San Pedro River. Changes in land management techniques such as increased grazing intensity and frequency due to diminishing pastureland, coupled with tremendous urban growth have altered the vegetation patterns and dynamics in the San Pedro River basin (Qi et al. 2000). In the last 30 years, the Sierra Vista census division has experienced a sizable increase

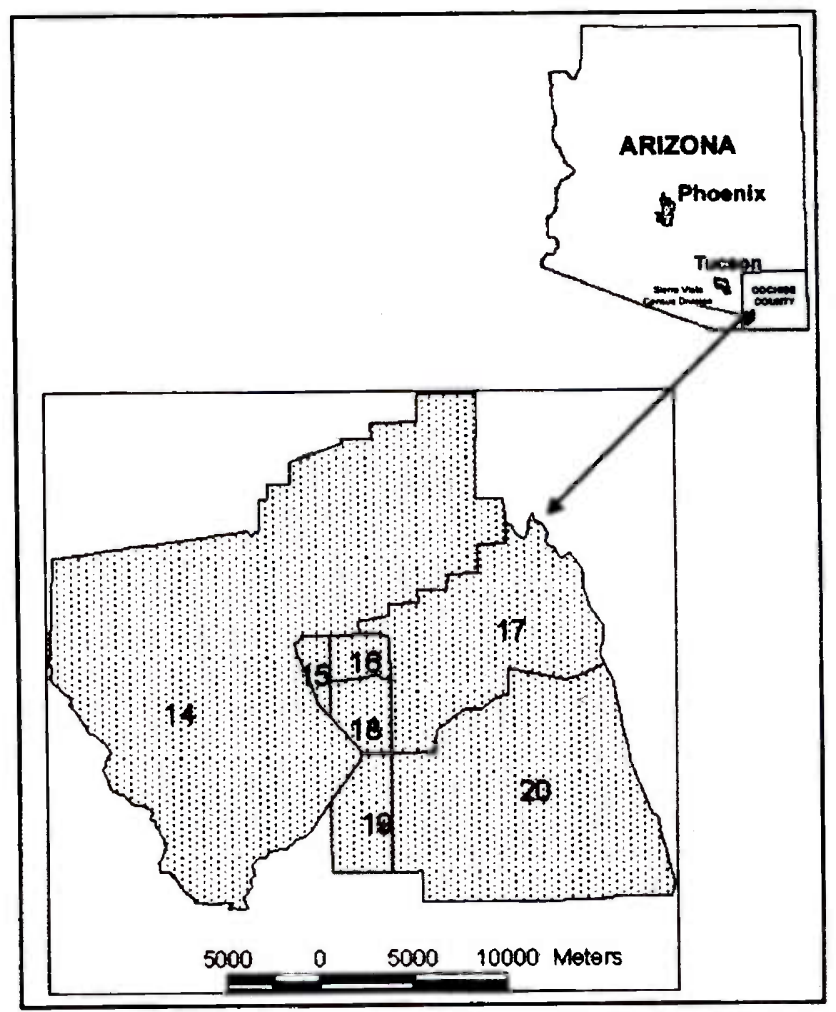

Fig. 1. Study site: Sierra Vista census division (census tracts 14-20), southeastern Arizona.

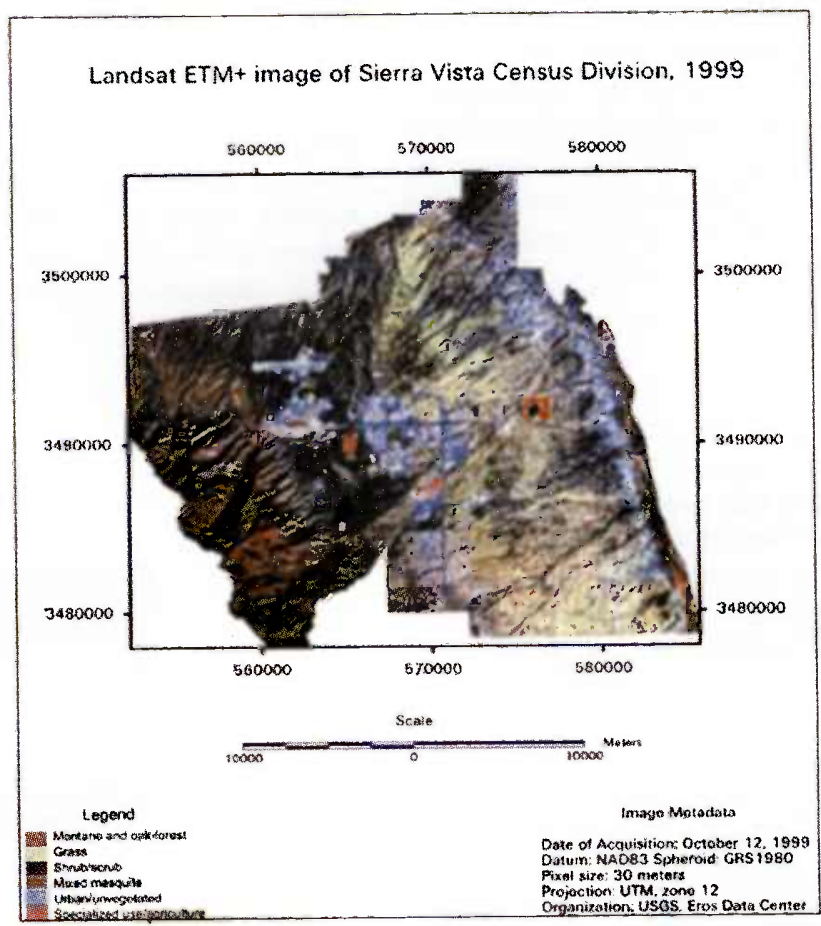

Fig. 2. Landsat ETM+4,3,2 composite image and metadata of Sierra Vista census division, 1999. 
Table 1. Land cover area totals and temporal assessment of land cover change, selected years.

\begin{tabular}{|c|c|c|c|c|c|c|c|c|c|}
\hline \multirow{3}{*}{$\begin{array}{l}\text { R: Rural } \\
\text { U: Urban }\end{array}$} & \multicolumn{3}{|c|}{ Land cover area totals } & \multicolumn{6}{|c|}{ Temporal assessment of land cover change } \\
\hline & & & & $1973-1985$ & $1973-1985$ & $1985-1999$ & $1985-1999$ & $1973-1999$ & $1973-1999$ \\
\hline & 1973 & 1985 & 1999 & $\begin{array}{l}\text { Net Gain/ } \\
\text { Loss }\end{array}$ & Gain/Loss & $\begin{array}{l}\text { Net Gain/ } \\
\text { Loss }\end{array}$ & Gain/Loss & $\begin{array}{l}\text { Net Gain/ } \\
\text { Loss }\end{array}$ & Gain/Loss \\
\hline & 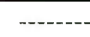 & --- (ha)- & 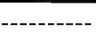 & (ha) & $(\%)$ & (ha) & $(\%)$ & (ha) & $(\%)$ \\
\hline R: Grass & 3493 & 2679 & 1882 & -814 & $-23 \%$ & -797 & $-30 \%$ & -1611 & $-46 \%$ \\
\hline R: Shrub/scrub & 7765 & 8194 & 8311 & 429 & $6 \%$ & 117 & $1 \%$ & 546 & $7 \%$ \\
\hline R: Mixed Mesquite & 3040 & 3241 & 3652 & 201 & $7 \%$ & 411 & $13 \%$ & 612 & $20 \%$ \\
\hline R: Urban/unvegetated & 1377 & 1562 & 1787 & 185 & $13 \%$ & 225 & $14 \%$ & 410 & $30 \%$ \\
\hline R: Agr./Specialized & 112 & 114 & 164 & 2 & $2 \%$ & 50 & $44 \%$ & 52 & $46 \%$ \\
\hline R: Water/Clouds & 74 & 71 & 64 & -3 & $-4 \%$ & -6 & $-8 \%$ & -9 & $-12 \%$ \\
\hline $\mathrm{U}$ : Grass & 7541 & 6340 & 6150 & -1201 & $-16 \%$ & -190 & $-3 \%$ & -1391 & $-18 \%$ \\
\hline U: Shrub/scrub & 9141 & 8908 & 8714 & -233 & $-3 \%$ & -194 & $-2 \%$ & -427 & $-5 \%$ \\
\hline U: Mixed Mesquite & 4709 & 4542 & 4470 & -167 & $-4 \%$ & -72 & $-2 \%$ & -239 & $-5 \%$ \\
\hline $\mathrm{U}$ : Urban/unvegetated & 3347 & 4531 & 5146 & 1184 & $35 \%$ & 615 & $14 \%$ & 1799 & $54 \%$ \\
\hline U: Agr./Specialized & 115 & 484 & 386 & 369 & $321 \%$ & -98 & $-20 \%$ & 271 & $236 \%$ \\
\hline U: Water / Clouds & 85 & 133 & 72 & 48 & $56 \%$ & -61 & $-46 \%$ & -13 & $-15 \%$ \\
\hline Total: Grass & 11034 & 9019 & 8032 & -2015 & $-18 \%$ & -987 & $-11 \%$ & -3002 & $-27 \%$ \\
\hline Total: Shrubscrub & 16906 & 17102 & 17025 & 196 & $1 \%$ & -77 & $0 \%$ & 119 & $1 \%$ \\
\hline Total: Mixed Mesquite & 7749 & 7783 & 8122 & 34 & $0 \%$ & 339 & $4 \%$ & 373 & $5 \%$ \\
\hline Total: Urban/unveg. & 4724 & 6093 & 6933 & 1369 & $29 \%$ & 840 & $14 \%$ & 2209 & $47 \%$ \\
\hline Total: Agr./Specialized & 227 & 598 & 550 & 371 & $163 \%$ & -48 & $-8 \%$ & 323 & $142 \%$ \\
\hline Total: Water/Clouds & 159 & 204 & 137 & 45 & $28 \%$ & -67 & $-33 \%$ & -22 & $-14 \%$ \\
\hline
\end{tabular}

in developed land due mostly to its increasing regional importance and popularity as a retirement spot. According to satellite data, in the period between 1973 and 1999, the total area of developed land rose from 4,724 ha to 6,933 ha-a $47 \%$ increase (Table 1). Most of the new urban growth took place over areas of native, perennial grasslands in the San Pedro River basin located in the southeastern quadrant of the census division. These transitional zones are characterized by unpaved roads, new utility corridors, and substantial residential development in the southeastern quadrant of the 1999 image (Fig. 3).

\section{Data Sources}

As typically is the case with most longterm, multi-temporal land use and land cover studies, this paper utilized satellite images from different sensors (Landsat 1 Multispectral Scanner (MSS), Landsat 5 Thematic Mapper (TM), and Landsat 7 Enhanced Thematic Matter $($ ETM+)) at various scales and resolutions for assessing land use and land cover change. The images were acquired during the growing season and their acquisition was relatively close to the maximum green-up time in the region (usually late August through early October). The dates of acquisition were 5 Sep. 1973 (MSS), 30 Sep. 1985 (TM), and 12 Oct. 1999 (ETM+). All the imagery was acquired from the Arizona Regional Image Archive. A political boundary coverage consisting of 7 census tracts comprising the Sierra Vista census division was used as the study area mask. The coverage was obtained from the USGS National Biological Information Infrastructure.

\section{Image Processing}

To remove the effects of atmospheric scattering from the images, Chavez's improved dark object subtraction (Chavez 1988) was utilized for the 1973 MSS image. For the 1985 TM and 1999 ETM+ images, a location-specific correction method, called the refined empirical line (Moran et al. 2001), was used for atmospheric correction. To correct the inherent geometric distortion, all images were resampled to 1973 MSS ground resolution, projected to the Universal Transverse Mercator projection, and the 1973 and 1985 images were co-registered to the orthorectified 1999 image with acceptable root mean square error of less than 0.05 pixel. Resampling and image-to-image registration was necessary for temporal assessments of land cover change and landscape indices. To reduce image noise and improve visual interpretability, images were modified using a 3-by-3 low-pass localaverage spatial filter before classification. 


\section{Image Classification}

A multispectral classification was performed using the supervised algorithm approach with maximum likelihood parametric decision rule. Known a priori land cover types were identified by combination of previously published vegetation maps, fieldwork data, recent personal field observations (utilized for the 1999 image classification), and personal interviews with U.S. Department of Agriculture personnel with over 30 years of classification experience in the region. The selected sites in the remotely sensed data represented homogeneous examples of these known land cover types. Before the supervised classification algorithm was applied to the images, image data were merged with topographic information. A mosaicked 7.5-minute 1990 USGS digital elevation model with 30 -meter contour interval was registered to the images to remove montane forest and oak woodland areas in the Huachuca Mountain region. Species that have very similar spectral characteristics (e.g., velvet mesquite (Prosopis velutina Woot.), oaks (Quercus L.), quaking aspen (Populus tremuloides Michx.), and evergreens) occupy quite different elevation ranges. The majority of the Upper Sonoran life zone species such as oaks, Mexican pinyon pine (Pinus cembroides Zucc.), juniper (Juniperus L.), as well as transition life zone species such as open ponderosa pine (Pinus ponderosa P.\& C. Lawson), characteristically found in elevations of 1,800 meters $(6,000$ feet $)$ and higher, were removed since grasslands, shrubs, and mesquite do not correspond to this elevation range. Use of ancillary elevation data thus aided in delineating the habitats and various associations between land cover characteristics associated with most anthropogenic disturbances. A 3-by3 majority filter was applied for post-classification smoothing in order to reduce the pixel-by-pixel spectral variability encountered by the classifier. Finally, the classification results were labeled based on the resource-oriented USGS Land Use/Land Cover Classification System Level I (Anderson et al. 1976).

Classification accuracy assessment of land use/land cover maps required comparison of 2 sources of information: (1) the imagery-derived classification data, and (2) reference data (ground truth). As a broad guideline, 50 ground points were selected outside of training areas using systematic random sampling and fieldchecked for each land cover category included in the classifications. Accuracy results for the 1973, 1985, and 1999 clas-

Table 2. Accuracy assessments for 1973, 1985, and 1999 supervised maximum likelihood classifications.

\begin{tabular}{|c|c|c|}
\hline Year & Producer's Accuracy & User's Accuracy \\
\hline \multicolumn{3}{|l|}{$\overline{1973}$} \\
\hline & Grass $(42 / 50)=84 \%$ & Grass $(42 / 52)=81 \%$ \\
\hline & Shrub $(41 / 50)=82 \%$ & Shrub $(41 / 53)=77 \%$ \\
\hline & Mesquite $(45 / 50)=90 \%$ & Mesquite $(45 / 58)=78 \%$ \\
\hline & Urban/unveg. $(45 / 50)=90 \%$ & Urban/unveg. $(45 / 47)=96 \%$ \\
\hline & Agriculture $(38 / 50)=80 \%$ & Agriculture $(38 / 40)=95 \%$ \\
\hline & Water $(50 / 50)=100 \%$ & Water $(50 / 50)=100 \%$ \\
\hline & Overall Accuracy: & $84 \%$ \\
\hline & KHAT-statistic: & $81 \%$ \\
\hline \multicolumn{3}{|l|}{1985} \\
\hline & Grass $(43 / 50)=86 \%$ & Grass $(43 / 48)=90 \%$ \\
\hline & Shrub $(44 / 50)=88 \%$ & Shrub $(44 / 56)=79 \%$ \\
\hline & Mesquite $(42 / 50)=84 \%$ & Mesquite $(42 / 50)=84 \%$ \\
\hline & Urban/unveg. $(45 / 50)=90 \%$ & Urban/unveg. $(42 / 49)=96 \%$ \\
\hline & Agriculture $(42 / 50)=84 \%$ & Agriculture $(42 / 49)=86 \%$ \\
\hline & Water $(50 / 50)=100 \%$ & Water $(50 / 50)=100 \%$ \\
\hline & Overall Accuracy: & $86 \%$ \\
\hline & KHAT-statistic: & $83 \%$ \\
\hline \multirow[t]{8}{*}{1999} & Grass $(44 / 50)=88 \%$ & Grass $(44 / 52)=85 \%$ \\
\hline & Shrub $(42 / 50)=84 \%$ & Shrub $(42 / 52)=81 \%$ \\
\hline & Mesquite $(43 / 50)=86 \%$ & Mesquite $(43 / 57)=75 \%$ \\
\hline & Urban/unveg. $(39 / 50)=78 \%$ & Urban/unveg. $(39 / 43)=91 \%$ \\
\hline & Agriculture $(43 / 50)=86 \%$ & Agriculture $(43 / 46)=93 \%$ \\
\hline & Water $(50 / 50)=100 \%$ & Water $(50 / 50)=100 \%$ \\
\hline & Overall Accuracy: & $84 \%$ \\
\hline & KHAT-statistic: & $81 \%$ \\
\hline
\end{tabular}

sifications are listed in Table 2. Producer's accuracy (measures errors of omission, e.g., 8 pixels that should have been classified as "grass" were omitted in 1973 in Table 2), users' accuracy (measures errors of commission, e.g., 10 pixels were improperly included in the "grass" category in 1973 in Table 2), overall accuracy (percent of pixels correctly classified), and the Kappa statistic (percent of how much a given classification is better than a classification resulting from chance) for the 3 images were all above 80 percent. Satellite and classified images for 1973, 1985, and 1999 are displayed in Figures 4, 5, and 6, respectively.

\section{Landscape Indices}

For complete ecological assessments of managed ecosystems, there is a need to quantify aspects of spatial configuration and composition that can be correlated with other ecological processes such as land use/land cover change and the role of fire. To that end, satellite images offer another unique facility for observing and documenting landscape structure, function, and change. There is a wide variety of landscape metrics and many software programs to calculate them (O'Neill et al. 1988, Turner and Gardner 1991). Many of these metrics have been shown to be highly correlated with one another (Riiters et al. 1995). In a factor analysis study,
Riiters et al. (1995) analyzed 55 landscape metrics for their statistical independence. They concluded that the information contained in the 55 metrics could be narrowed down to 5 metrics. These metrics have also been proposed for implementation as watershed integrity indicators, landscape stability and resilience indicators, and biotic integrity and diversity indicators (U.S. EPA 1997). The metrics include patch density, edge density, Shannon's Diversity Index, Interspersion and Juxtaposition Index, and Contagion. These indices were derived directly from the classified images using the FRAGSTATS software (McGarigal and Marks 1995). However, because the Patch Density, Edge Density, and Shannon's Diversity Index are dependent on the size of the smallest spatial unit mapped and the number of different categories distinguished, the 1973 classified image was resampled to the spatial resolution of 1985 and 1999 images, i.e., 30 meters. Shannon's Diversity Index, a structural measure of the area distribution of classes, did not display any variation due to census division's large area extent, and was not interpreted. In addition, the census division was partitioned into rural and urban zones based on census tract population statistics before landscape metrics were calculated for improved interpretation of different land use patterns and associated spatial structures. The U.S. 


\section{MSS image and classification results}
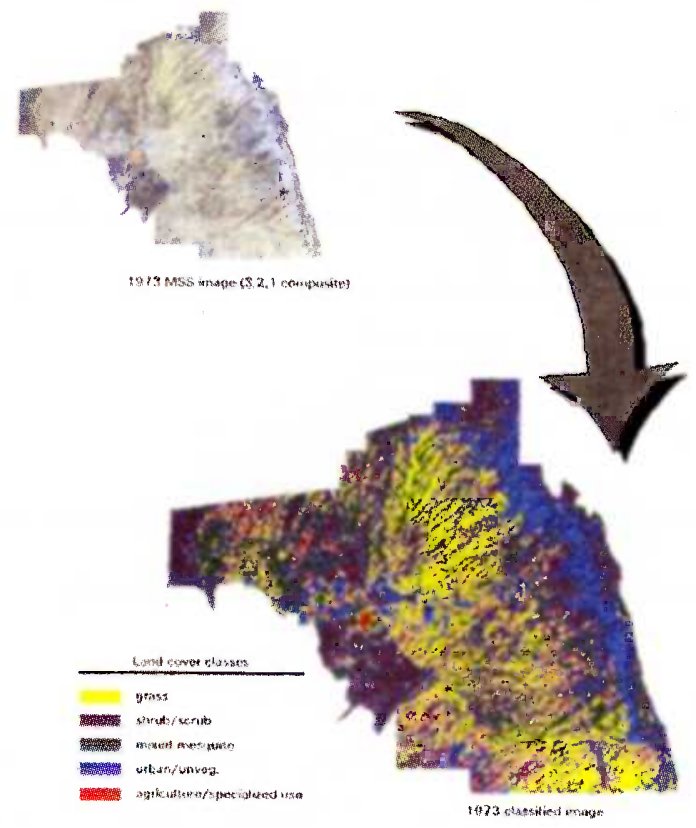

Fig. 4. 1973 MSS image and classification results.
1985 TM image and classification results
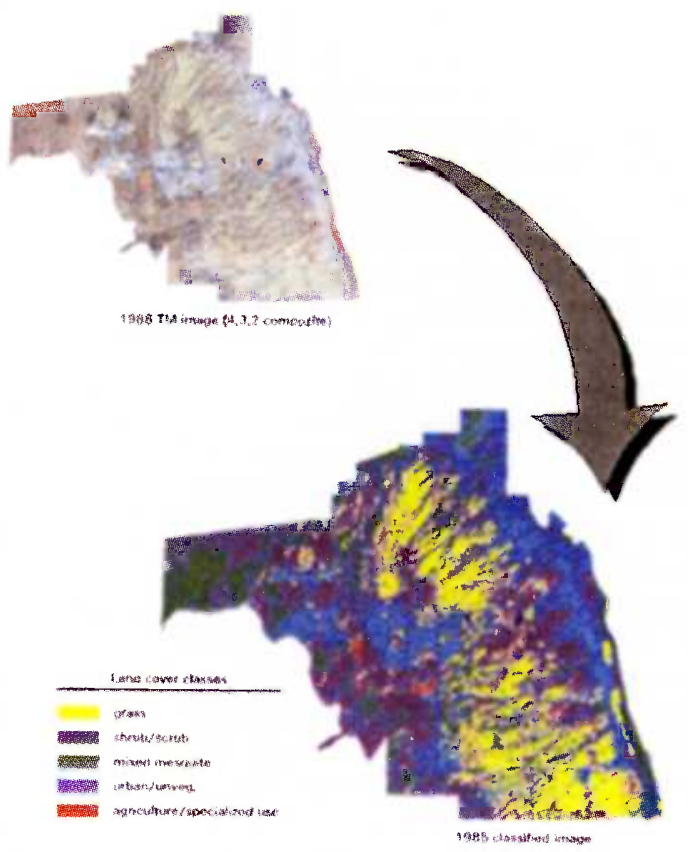

Fig. 5. 1985 TM image and classification results.
Census Bureau defines a rural area as one that is not urban (U.S. Department of Commerce 1992). "Urban" is defined as either an urbanized area or places with populations of 2,500 or more outside urbanized areas. An urbanized area includes places and their adjacent densely settled surrounding territory that together have a minimum population of 50,000 (U. S. Department of Commerce 1992). Two regions of census tracts meeting the defined criteria for urban and rural areas of the census division were selected from the imagery (Fig. 7). Descriptions of the metrics, how to interpret their value, and outputs are listed in Table 3. The reader may refer to McGrigal and Marks (1995) for a more complete assessment of landscape metrics.

\section{Results and Discussion}

\section{Land Cover Changes}

The expected general model for the land cover classes should describe a strong differentiation between each class. Specifically, urban/unvegetated cover in the urban sector should substantially increase, and shrub and mesquite covers should replace grass cover in rural areas. Land cover area totals derived from the
1973, 1985, and 1999 classified imagery clearly reveal endemic changes unique to rural and urban landscapes of the census division. Table 1 and Figure 8 reveal substantial loss of grass cover in both rural and urban sectors of the census division. Between 1973 and 1999, net loss of grass cover for rural zones was $46 \%$, and of the 1,611 grassland ha converted in rural areas, $65 \%$ was replaced by shrub and mesquite. During the same time, urban zones experienced an 18 and 5\% net loss in grass and shrub/mesquite, respectively,

and $69 \%$ of this loss was converted to urban/unvegetated land cover. These results clearly suggest different land use mechanisms, and drivers of land cover change for rural and urban areas of the census division. Although loss of grass cover is significant in both sectors, shrub and mesquite invasion is apparent in the rural areas, whereas built areas in the urban sector replaced grass as well as shrub and mesquite. Both of these land use mechanisms of conversion result in habitat degradation on native grasslands.

Table 3. Outputs and descriptions of landscape metrics.

\begin{tabular}{lllllc}
\hline \hline & & PD & ED & IJI & Contagion \\
\hline \multirow{2}{*}{$1973(30 \mathrm{~m})$} & Rural & 35.3 & 128.6 & $(\%)$ & $(\%)$ \\
& Urban & 35.6 & 133.4 & 51.2 & 39.8 \\
\multirow{1}{*}{1985} & Total & 33.6 & 128.0 & 61.5 & 41.3 \\
& Rural & 81.7 & 184.5 & 56.7 & 40.4 \\
& Urban & 87.1 & 189.5 & 66.9 & 42.1 \\
1999 & Total & 82.2 & 186.7 & 57.5 & 37.4 \\
& Rural & 128.3 & 229.3 & 43.0 & 39.3 \\
& Urban & 170.1 & 260.2 & 69.2 & 31.2 \\
& Total & 145.8 & 242.7 & 59.2 & 36.1 \\
\hline
\end{tabular}

PD: Patch Density - expresses the number of patches within the entire reference unit on a per area basis ( 100 ha) ED: Edge Density - length of all borders between different classes in a reference area divided by the total area of the reference unit $(100 \mathrm{ha})$

IJI: Interspersion and Juxtaposition Index - analyzes the adjacency of

each patch with all other patch types, and measures the extent to which classes are interspersed.

Contagion: measures the extent to which classes are aggregated or clumped. 


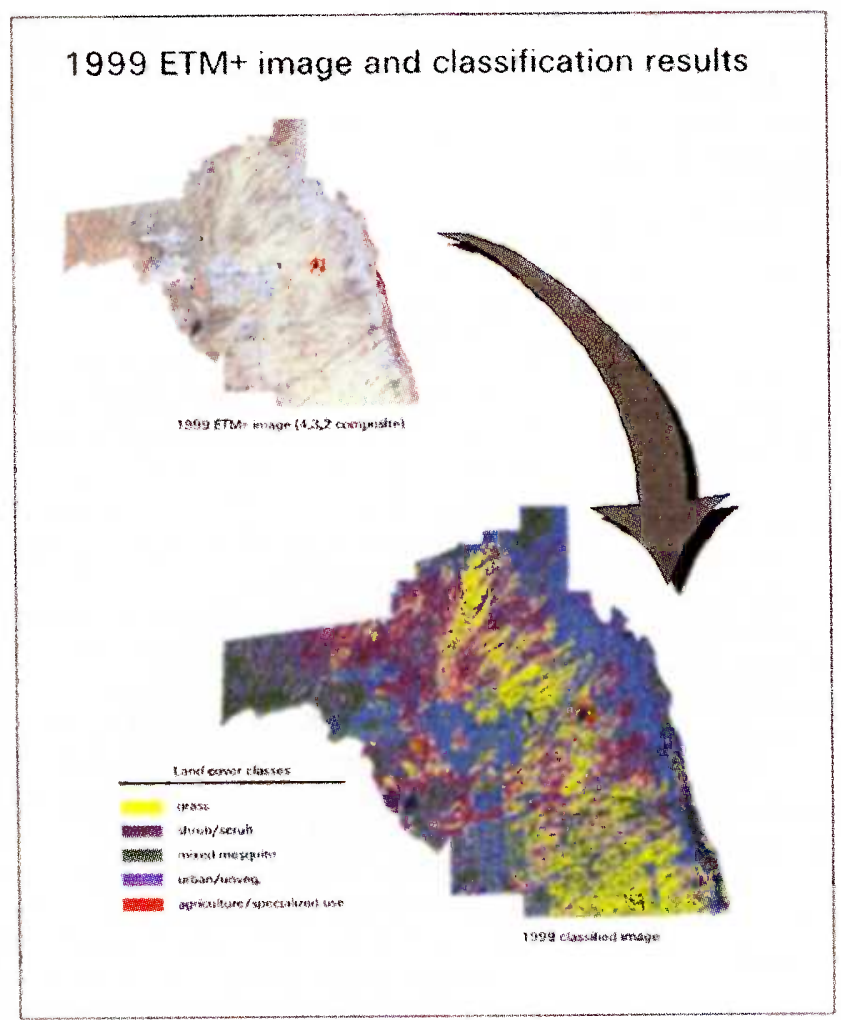

Fig. 6. 1999 ETM+ image and classification results.
Urban and non-urban (rural) sectors

of Sierra Vista census division, 1999
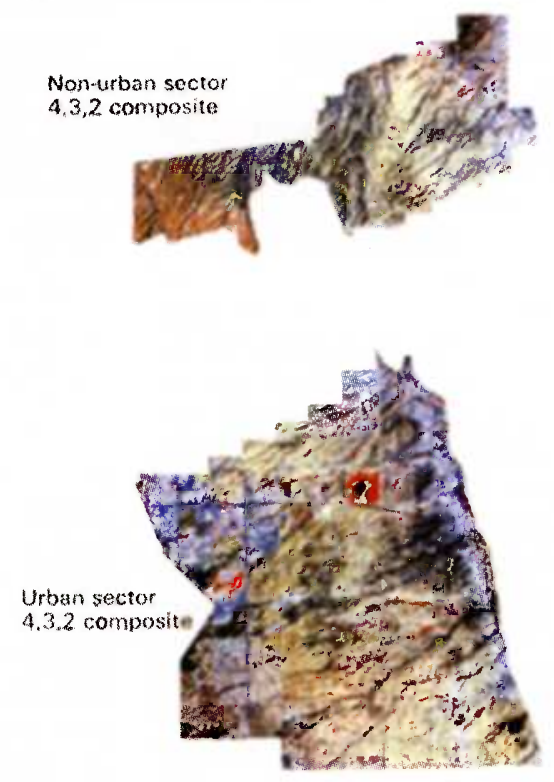

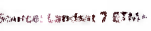

Fig. 7. Urban and non-urban (rural) sectors of Sierra Vista census division, 1999.

\section{Landscape Changes}

The first expected general model for landscape change detection was that the farther away the site from the urban center (located in center of Fig. 2), the lower the fragmentation and shape complexity. Hence, the rural sector was expected to display lower values for Edge Density, Patch Density, Interspersion and Juxtaposition Index, and higher values for Contagion as compared to the urban sector in a single scene. In a time series, rural indicators should remain constant in a healthy ecosystem. The second model states that the urban sector should have higher shape complexity since it consists of a mixture of roads, residential, business, and industrial areas. Visibly, the urban area is more fragmented than non-urban areas in the census division and should have higher fragmentation values. In a time series, urban Edge Density, Patch Density, and Interspersion and Juxtaposition Index should increase, and Contagion should decrease. Table 3 shows the results for landscape indices with respect to different sectors and years.

The output indicates substantial and increasing grassland disturbance in both rural and urban sectors between 1973 and 1999. Urban areas have higher shape com- plexity, or modification (Edge Density) values than rural areas in both space and time although the difference is not substantially large. Urban fragmentation values over space and time (increasing Interspersion and Juxtaposition Index, Patch Density and decreasing Contagion) indicate dissected and equally adjacent classes in an expanding urban landscape. However, significant modification is also occurring in the rural landscape. From 1973 to 1999, the northwest corner of the rural census division experienced a substantial increase in mesquite, and the northeast quadrant witnessed significant conversion of grass to shrub (Figs. 4, 5, and 6). Clumping (decreasing Interspersion and Juxtaposition and increasing contagion) and high modification (increasing Edge Density and Patch Density) in rural areas, coupled with substantial loss of grass cover identified by land cover change indicate expanding communities of homogeneous and aggregated shrub and mesquite. The increasing rural modification and urban fragmentation of grasslands indicate that the habitat

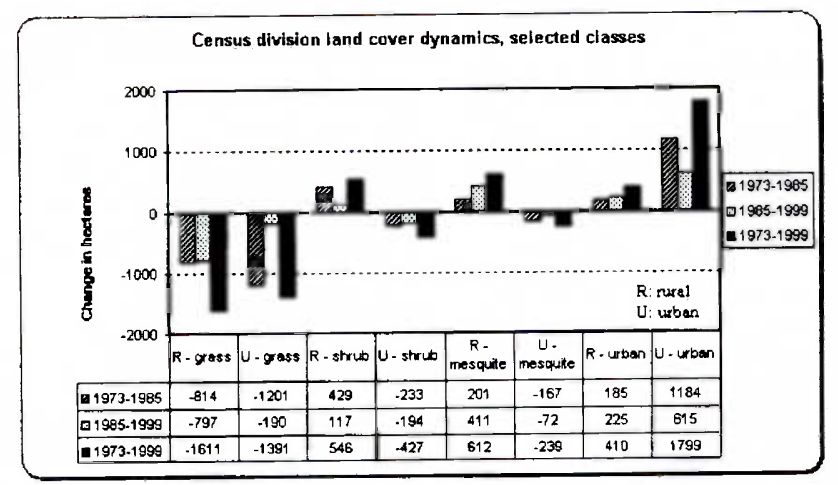

Fig. 8. Census division land cover dynamics, selected years. 
for grasslands is becoming more unsuitable for community stability and survival in the census division.

\section{Land Cover and Landscape Assessment}

A basic premise of this paper is that effects of anthropogenic and natural stressors in the census division can be interpreted by remote sensing. The introduction of urban development and invasive shrub and mesquite species raises a number of questions about impact on the native grasslands and when this is coupled with changing external forcing mechanisms such as a potentially rapid climate change, then it is necessary to examine even more carefully these introductions.

Development pressures in the Sierra Vista census division hold crucial implications for grassland sustainability. Changes in the extent and pattern of urban land cover reveal that grass as well as shrub and mesquite communities are being fragmented and converted to built landscapes. A developing urban landscape has disproportionate influence on the grassland ecosystem due directly by increased fragmentation, complexity, and conversion, and also indirectly by fire suppression policies typically enacted to protect rural and suburban subdivisions.

Declining fires in the census division reported in Table 4, coupled with findings from land cover and landscape indicators strongly suggest that a sustained, longterm program of fire suppression can produce dramatic changes in community structure and function, particularly if soils do not limit shrub establishment (Holechek et al. 1998). Many grass species common in southeastern Arizona including blue (Bouteloua gracilis (Willd. Ex Kunth) Lag. Ex Griffiths) and hairy grama (Bouteloua hirsute Lag.), plains lovegrass (Eragrostis intermedia A.S. Hitchc.), as well as the introduced Lehmann lovegrass (Eragrostis lehmanniana Nees), recover much more quickly following early growing-season fires than large, decadent scrub species because their rhizomatous roots are located below the soil surface, and thus usually escape lethal temperatures (Glendening and Paulsen 1955). In the absence of fire, desert grasslands develop dense, woody overstories and forbs that significantly reduce herbaceous grass production (Engle et al. 1998). The resulting lack of fine fuel reduces fire intensity and frequency, and the community changes from grassland to shrubland (Brown and Lowe 1980). Ideally, before this threshold between grassland and shrubland is crossed, land management strategies should be reevaluated. Once woody plants dominate a site, fire alone cannot return it to the earlier composition since fine fuel is too scarce and discontinuous to produce fires of sufficient intensity to kill woody plants. Thus, woody plants become permanent occupants of the site. Without herbicides or mechanical shrub control the change is irreversible (Dormaar and Willms 1998). The net result of the absence of periodic fires is a reduction in herbaceous grass production (Holechek et al. 1998).

Increasing demand for residential and industrial development, hobby farms, ranchettes, and land speculation are other common factors influencing the increase in built land in the census division. However, identification of these human drivers, i.e., causal factors, of land use and land cover change requires substantial in-situ ranchlevel surveys, economic indicators and modeling, and land use modeling techniques that are beyond the scope of this paper. Similarly, in-situ data relating to soil conditions, grass vigor, and grazing techniques were not available on a consistent basis.

Another dramatic change in the grasslands in greater Sierra Vista between 1973 and 1999 has been the rapid increase of shrubs and mesquite. In the southwestern United States, range productivity on most sites can be greatly increased by control of velvet mesquite, and American tarwort (Flourensia cernua DC.) (Holechek et al. 1998). It is well known that mesquite competes vigorously with warm-season perennial grasses. The inverse relationship between density of mesquite and perennial grass production has been widely recognized (Reynolds and Martin 1968). The roots of mesquite and acacia (Acacia $\mathrm{P}$. Mill.) are generally more extensive than those of herbaceous grass species, and allow the plants to tap soil water sources at greater depths.

The likely causes for the shrub and mesquite increase include (1) a reduction in the frequency and intensity of wildfires due largely to overgrazing following settlement and fire suppression; (2) a decline in natural perennial grasses, which, when healthy and dense, can reduce mesquite seedling establishment; (3) increased dissemination by livestock and/or Merriam kangaroo rats (Dipodomys merriami) of scarified mesquite seed; (4) hoof damage to ground cover and soil compaction by livestock resulting in reduced moisture in the upper layers of soil, which hinders grass establishment and growth; and (5) land clearing and cultivation (Bahre and
Shelton 1993). These management-related causation factors have contributed greatly to the demise of grass cover in the Sierra Vista census division.

\section{Conclusions}

The ecological assessment of the Sierra Vista census division is an attempt to gain more scientific knowledge than we now possess of the physical and anthropogenic extent, character, and consequences of land conversion. Of the major physical processes of global change-climatic change, alteration of biogeochemical cycles, and land use - the most influential agent of future change in grasslands will be land use. If the current land use patterns remain unchanged, the most likely outcome in southwestern United States semi-arid ecosystems is an extensive transformation of the grasslands, either by degradation through the encroachment of invasive species and unsustainable use or by conversion to urban use and cover. These changes will be principally, but not exclusively, driven by the effect of a growing human population. To that end, remote sensing is vital for detecting and quantifying changes in land use and land cover, monitoring spatial composition and configuration, and quantifying the impact of grazing strategies and fire suppression and other subtle forcing factors on the land surface.

Between 1973 and 1999, rapid urbanization and land management practices contributed to significant grassland conversion in greater Sierra Vista. According to satellite data between 1973 and 1999, grasslands were reduced by $46 \%$ in rural areas, and $18 \%$ in urban areas, and $27 \%$ of the grass cover in 1973 was eradicated by 1999 in the census division (Table 1). During the same period, shrub and mesquite cover increased by 7 and $20 \%$, respectively, and gained 1158 ha in rural areas. Landscape indices in Table 3 also indicate a large degree of conversion due to replacement of native grasses by fragmented urban development, and a substantial increase in aggregated patches of woody shrubs and trees at the expense of native grasses.

If the present rate of urban growth is sustained and current ecological trends continue, further conversion, fragmentation, and degradation of grasslands in greater Sierra Vista will be inevitable. Of local and regional significance is not just the area converted but also the area modified, or changed in ecological condition. Grasslands in the rural sector are degrad- 
ing, with such consequences as soil erosion, changed floristic composition, diminished productivity, and habitat value for wildlife. In addition, population growth in the urban sector is not only leading to conversion of land cover from grass to urban, but is also an additional contributor to land fragmentation and degradation.

\section{Literature Cited}

Anderson, J.R., E. Hardy, J. Roach, and R. Witmer. 1976. A land-use and land-cover classification system for use with remote sensor data. U.S. Geol. Surv. Professional Paper No. 964. Denver, Colo.

Bahre, C.J. and M.L. Shelton. 1993. Historic vegetation change, mesquite increases, and climate in southeastern Arizona. J. Biogeography. 20:489-504.

Brown, D.E. and C.H. Lowe. 1980. Biotic communities of the southwest. U.S. Dept.Of Agri. Gen. Tech. Rep., RM-78. Salt Lake City, Ut.

Chavez, P.S. Jr. 1988. An improved darkobject subtraction technique for atmospheric scattering correction of multispectral data. Remote Sensing Environ. 24:459-479.

Dormaar, J.F. and W.D. Willms. 1998. Effect of forty-four years of grazing on fescue grassland soils. J. Range Manage. 51:122-126.
Engle, D.M., R.L. Mitchell, and R.L. Stevens. 1998. Late growing-season fire effects in mid-successional tall-grass prairies. J. Range Manage. 51:115-121.

Glendening, G.E. and H.A. Paulsen, Jr. 1955. Reproduction and establishment of velvet mesquite as related to invasion of semidesert grasslands. U.S. Dept. of Agr. Tech. Bull. 1127. Denver, Colo.

Holechek, J.L., C.H. Herbel, and R.D. Pieper. 1998. Range management. Princeton Hall, Upper Saddle River, N.J.

McGarigal, K. and B. Marks. 1995. FRAGSTATS: Spatial pattern analysis program for quantifying landscape structure. USDA Forest Serv. Gen. Tech. Rep. PNWGTR-351.

Moran, M.S., R. Bryant, T.R. Clarke, M.P. Gonzalez-Dugo, W. Ni, Y. Nouvellon, J. Qi, and K. Thome. 2001. A refined empirical line approach for reflectance factor retrieval from Landsat-5 TM and Landsat-7 ETM+. Remote Sensing Environ. 78:71-82.

Nemani, R.R., S.W. Running, R.A. Pielke, and T.N. Chase. 1996. Global vegetation cover changes from coarse resolution satellite data. J. Geophys. Res. 101:7157-7162.

O'Neill, R.V., S.W. Christensen, V.H. Dale, D.L. DeAngelis, R.H. Gardner, R.L. Graham, B. Jackson, J.R. Krummel, B.T. Milne, G. Sugihara, M.G. Turner, B. Zygmunt. 1988. Indices of landscape pattern. Landscape Ecol.. 1:153-162.

Qi, J., A. Chehbouni, G. Dedieu, D.C. Goodrich, P. Heilman, Y.H. Kerr, R.C. Marsett, M.S. Moran, and X.X. Zhang. 2000. Spatial and temporal dynamics of vegetation in the San Pedro River basin area. Agr. Forest Met. 105:55-68.
Reynolds, H.G. and S.C. Martin. 1968. Managing grass-shrub cattle ranges in the southwest. U.S. Dept. of Agr. Handb. 162. Denver, Colo.

Ridd, M. 1995. Exploring a V-I-S model for urban ecosystem analysis through remote sensing: comparative anatomy of cities. J. Remote Sensing. 16: 2165-2185.

Riiters, K.H., R.V. O'Neill, C.T. Hunsaker, J.D. Wickham, D.H. Yankee, S.P. Timmins, K.B. Jones, and B.L. Jackson. 1995. A factor analysis of landscape pattern and structure metrics. Landscape Ecol. 10:23-39.

Skole, D.L., C.O. Justice, A.C. Janetos, and J.R.G. Townshend . 1997. A land cover change monitoring program: strategy for an international effort. Mitigation and Adaptation Strategies for Global Change. 2:157-175

Turner, M.G. and R.H. Gardner. 1991 Quantitative Methods in Landscape Ecology. Springer-Verlag. New York, N.Y.

United States Department of Commerce, Bureau of the Census. 1992. Population and Housing Statistics. Washington, D.C.

U.S. Environmental Protection Agency (U.S. EPA). 1997. Environmental Monitoring and Assessment Program (EMAP): Research Strategy. EPA/620/R-98/001. U.S. Environ. Protection Agency. Washington, D. C.

U.S. Environmental Protection Agency (U.S. EPA). 1999. Guidelines for Ecological Risk Assessment. EPA/630/R-95/002F. United States Environmental Protection Agency. Washington, D. C. 